\title{
Climate Change Information Source and Indigenous Adaptation Strategies of Cucumber Farmers in Enugu State, Nigeria
}

https://dx.doi.org/10.4314/jae.v22i2.4

\author{
Asadu, Anthonia N. \\ Department of Agricultural Extension, University of Nigeria, Nsukka \\ Email: anthonia.asadu@unn.edu.ng \\ Phone Number: +2348166979076 \\ E -mail: anthonia.asadu@unn.edu.ng
}

\section{Ozioko, Remigus I.}

Department of Agricultural Extension, University of Nigeria, Nsukka Email: ikechiozioko@gmail.com, remigius.ozioko@unn.edu.ng

Phone: +2347038845649

\section{Dimelu, Mabel. U.}

Department of Agricultural Extension, University of Nigeria, Nsukka. mabel.dimelu@unn.edu.ng +2348185631828.

\section{Abstract}

The study assessed the climate change information source and the indigenous adaptation strategies of cucumber farmers in Enugu State. A multi-stage sampling technique was used in selecting 80 respondents. Data were elicited using structured interview schedule and presented in percentage and mean scores. Findings showed that the majority (92.5\%) of cucumber farmers never had contact with extension workers. Information on climate change was mainly from neighbours/friends and personal experience. The indigenous strategies employed for climate change adaptation were organic manure $(\bar{x}=2.91)$, crop diversification $(=2.75)$, early harvesting $(\bar{x}=2.74)$ planting early maturing varieties $(\bar{x}=2.59)$, prompt weeding $(\bar{x}=2.79)$ among others. The major challenges encountered by the respondents included poor market facility $(\bar{x}=2.36)$, non-availability of credit facility $(\bar{x}=2.74)$, nonavailability of storage facilities $(\bar{x}=2.75)$, high cost of labour $(\bar{x}=2.48)$, poor access to information sources $(\bar{x}=2.30)$, limited income $(\bar{x}=2.58)$. It was recommended that high level awareness via media campaign be employed by government extension agency to educate cucumber farmers on climate change issues. Also, a sustainable national climate change policy should be championed by the Ministry of Agriculture to build farmers capability to adapt to climate change. Also, government should intervene in the issues of credit, input/facilities and map out a framework to guarantee access to land by farmers for enhanced resilience and expand of production.

Keywords: Climate change, indigenous, information, adaptation, strategies, cucumber, farmers 


\section{Introduction}

Realization of the potential of vegetable production has made farmers to embark on the production, not just for immediate consumption, but also for sale to improve their livelihood. Vegetable production increases farmers' access to cash for basic necessities of life and promoting farm production. Production of vegetable is no longer made in the backyard for home consumption, rather in a large scale production for domestic and export markets (Heinemann, 2012). The fruit of cucumber, which is soft and succulent is consumed raw (salad) or cooked with other vegetables (Shetty and Wehner, 2002; Arunkumar, Ramanjinapa \& Ravishankar, 2011).

The nutritional composition of cucumber fruit per $100 \mathrm{~g}$ edible portion is carbohydrate $(3 \%)$, protein $(1 \%)$, total fat $(0.5 \%)$ and dietary fibre (1\%) (USDA, National Nutrient Data Base, 2014). Like other agricultural ventures, cucumber production solely depends on climate for optimal yield. The climatic condition required for optimal life cycle is a warm climate. This implies that expected yield of cucumber production can be affected with a change in climate. Climate change refers to the long-term significant change in the "average weather" that a given region experiences (IPCC, 2007). Generally, farmers have encountered series of loses as a result of change in climate (Apata, Samuel \& Adeola, 2009; Ozor, 2009 \& IPCC, 2007).

The National Bureau of Statistics estimates that 70 per cent of fruits and vegetables produced in the country are wasted, basically due to crude methods used by farmers in the face of climate change (NBS, 2015). Consequently, farmers adopt several indigenous measures to adapt to the negative impact of climate change. According to Odoemelam \& Ajuka (2015), indigenous adaptive strategies are practices that are based on experience, often tested over time, and adapted to local culture for natural resources management. Studies have explored indigenous ways farmers cope with climate change, considering their socioeconomic status (Enete, Madu, Mojekwu, Onyekuru, and Oluwasusi \& Tijani, 2013). However, the study was on farming households, irrespective of crops or animals produced. Given differences in environmental and climate requirements of crops, indigenous adaption strategies based on crops were not addressed.

Production of cucumber is fast becoming popular among farming households in Enugu State, due to its high nutritional and medicinal values. There is limited information on challenges of farmers, particularly in adapting production to the problem of climate change. Research investigation into adaptive measures adopted by farmers is apt to documentation, dissemination and informed tailored training and for increased production. The study assessed the climate change information source and the indigenous adaptation strategies of cucumber farmers in Enugu State. The specific objectives were to:

1. describe the socio-economic characteristics of cucumber farmers;

2. ascertain sources of information on climatic change;

3. identify the indigenous climate change adaptation strategies used by farmers

4. ascertain challenges faced by farmers in adapting to climate change. 


\section{Methodology}

The study was carried out in Enugu State, Nigeria. Enugu State is one of the south eastern states that make up the thirty-six states in Nigeria. Her land mass is $8,022.95 \mathrm{Km}^{3}$ and population of 3,267,837 (National Population Commission, 2006). Major crops cultivated includes; cassava, yam, cocoyam, vegetables, oil palm etc. The population for the study comprised all cucumber farmers in Enugu State. A multi-stage sampling technique was used. Two senatorial zones (Enugu North and Enugu West) were selected from the three senatorial zones using simple random sampling technique. From the two senatorial zones selected, one local government each (Nsukka and Udi) was purposively selected based on intensity of cucumber production. Two town communities were selected from each LGA, as follows Obimo \& Lejja (Nsukka LGAs); Nsude and Ngwo (Udi LGAs), giving a total of four town communities. In each of the selected town communities, two village communities were selected, making a total of eight (8) village communities. Ten cucumber farmers were selected form each town community using snowball technique out of the selected villages ten (10) cucumber farmers each were selected using snow-ball. This gave a total of 80 respondents for the study. Data were collected by the use of structured interview schedules, and presented using descriptive statistics.

\section{Results and Discussion}

\section{Personal characteristics of cucumber farmers}

Table 1 shows that the majority $(56.3 \%)$ of the respondents were male, married $(67.5 \%)$ and within the age range of $21-30$ years $(41 . \%)$. This shows that production of cucumber is dominated by married male folk, who are still within productive age. This could be explained by increasing diversification of farming, high demand and the short growing period, thereby increasing the economic value of marginal lands. Besides, cucumber production is less labour and capital intensive and could be managed in a small scale with limited capital and family labour. Availability of market and relatively longer shelve life are also good incentive for its production. The majority, $(71.3 \%)$ of cucumber production was carried out in less than one (1) acre ( $0.41 \mathrm{ha})$ of land. The average acres of land used for cucumber farming was 1 . This means that production is still on subsistence level, probably due to limited fund and market for the produce. This contradicts Heinemann (2012) who noted that vegetable production such as cucumber are no longer made in the backyard for home consumption, rather to a larger scale production for domestic and export markets. 
Creative commons User License: CC BY-NC-ND

Abstracted by: EBSCOhost, Electronic Journals Service (EJS),

Google Scholar, Journal Seek, Scientific Commons,

Food and Agricultural Organization (FAO), CABI and Scopus
Journal of Agricultural Extension

Vol. 22 (2) June, 2018

ISSN(e): 24086851; ISSN(Print); 1119944X

http://journal.aesonnigeria.org

Email: editorinchief@aesonnigeria.org

Table 1: Personal characteristics of respondents

\begin{tabular}{|c|c|c|}
\hline Variables & Percentage & Mean \\
\hline \multicolumn{3}{|l|}{ Sex } \\
\hline Male & 56.3 & \\
\hline Female & 43.8 & \\
\hline \multicolumn{3}{|l|}{ Age(years) } \\
\hline$\leq 20$ & 1.3 & \\
\hline $21-30$ & 41.3 & \\
\hline $31-40$ & 18.8 & 37.0 \\
\hline $41-50$ & 18.8 & \\
\hline $51-60$ & 17.5 & \\
\hline$\geq 60$ & 2.5 & \\
\hline \multicolumn{3}{|l|}{ Marital Status } \\
\hline Single & 22.5 & \\
\hline Married & 67.5 & \\
\hline Divorce & 2.5 & \\
\hline Widowed & 7.5 & \\
\hline \multicolumn{3}{|l|}{ Farm Size (In acre) } \\
\hline Below 1 & 71.3 & \\
\hline $1-2$ & 26.3 & 1.00 \\
\hline $3-4$ & 2.5 & \\
\hline \multicolumn{3}{|l|}{5 and above } \\
\hline \multicolumn{3}{|l|}{ Farming } \\
\hline \multicolumn{3}{|l|}{ Experience (years) } \\
\hline Below 5 & 60.0 & \\
\hline $6-10$ & 38.8 & \\
\hline $11-15$ & 1.3 & 5.00 \\
\hline 16 and above & 60.0 & \\
\hline \multicolumn{3}{|l|}{ Annual Income (N) } \\
\hline Below 100,000 & 53.8 & \\
\hline $100001-200,000$ & 30.0 & \\
\hline $300001-400,000$ & 10.0 & 15870.26 \\
\hline 400001 and above & 6.3 & \\
\hline
\end{tabular}

Source: Field survey, 2017

\section{Institutional Characteristics of Cucumber Farmers}

Table 2 shows that $96.2 \%$ of cucumber famers are literate and greater proportion completed primary (27.5\%) and secondary education $(21.3 \%)$. The farmers had an average of 5 years of farming experience in cucumber production. Relatively, production of cucumber is new, but the literacy level of the respondents' portent great prospect for increase production, especially with regard to taking inform farm decision, innovativeness and adoption of technologies in the sector.

About $62 \%$ of farmers are involved in farming as primary occupation. It is possible the majority of these farmers solely depend on farming as their source of livelihood. Thus increasing production is important to enhance livelihood of farmers. The cucumber produced were sold in local market. This could be as result of poor 
transportation, proximity to urban market and cost of carriage. Besides, the quantity produced is a determinant factor, since production is mainly at subsistence level.

Furthermore, the majority (88.8\%) of cucumber farmers do not have access to credit (Table 2). Also, $85.0 \%$ sourced fund for farming from personal savings. This is grossly inadequate for large scale commercialization of the crop and could limit their entrepreneurship and invariably the income generation. It could also decrease farmers' efficiency by adoption of new technologies that can enhance production.

Generally, farmers lack access to credit majorly due to lack of collateral and insurance for agricultural investments.

The majority $(67.5 \%)$ of the cucumber farmers did not belong to any social organization. This agrees with the finding of Bamire, Abdoulaye, Sango, et., al (2010), that about $(70 \%)$ of farmers in Oyo State did not belong to any farmers' associations. It is not surprise because cucumber producers are relatively new in the business and may not have been mobilized into groups by extension workers. However, participation in social organization has advantages of enabling farmers to exchange ideas, explore the economics of scale and access assistance for production. 
Creative commons User License: CC BY-NC-ND

Abstracted by: EBSCOhost, Electronic Journals Service (EJS), Google Scholar, Journal Seek, Scientific Commons,

Food and Agricultural Organization (FAO), CABI and Scopus
Journal of Agricultural Extension

Vol. 22 (2) June, 2018

ISSN(e): 24086851; ISSN(Print); 1119944X

http://journal.aesonnigeria.org

Email: editorinchief@aesonnigeria.org

Table 2: Distribution of respondents based on their institutional characteristics

\begin{tabular}{|c|c|}
\hline Variables & Percentage \\
\hline \multicolumn{2}{|l|}{ Level of Education } \\
\hline No formal education & 3.8 \\
\hline Primary education attempted & 13.8 \\
\hline Primary education completed & 21.3 \\
\hline Secondary education attempted & 17.5 \\
\hline Secondary education completed & 27.5 \\
\hline Tertiary education & 16.3 \\
\hline \multicolumn{2}{|l|}{ Major occupation } \\
\hline Farming & 62.5 \\
\hline Trading & 26.3 \\
\hline Civil service & 6.3 \\
\hline Retiree & 2.5 \\
\hline Artisan & 2.5 \\
\hline \multicolumn{2}{|l|}{ Marketing channels } \\
\hline Farm gate & 3.8 \\
\hline Local market & 57.5 \\
\hline Road side & 38.8 \\
\hline Urban market & - \\
\hline \multicolumn{2}{|l|}{ Visited by extension worker } \\
\hline \multirow{2}{*}{\multicolumn{2}{|c|}{ If yes, how often }} \\
\hline & \\
\hline $1-3$ times & 66.7 \\
\hline 4-6 times & 33.3 \\
\hline 7-9 times & - \\
\hline Above 10 times & - \\
\hline \multicolumn{2}{|l|}{ Access to credit } \\
\hline Yes & 11.3 \\
\hline \multicolumn{2}{|l|}{ If yes, where they obtain credit } \\
\hline Isusu group & 33.3 \\
\hline Financial institution & 66.7 \\
\hline Town union & - \\
\hline Cooperative society & - \\
\hline \multicolumn{2}{|c|}{ Membership of social organization } \\
\hline Yes & 32.5 \\
\hline \multicolumn{2}{|l|}{ If yes, type of organization } \\
\hline Farmers' group & 23.1 \\
\hline Cooperative society & 57.7 \\
\hline Thrift society & 7.7 \\
\hline Social club & 3.8 \\
\hline Religious group & 7.7 \\
\hline \multicolumn{2}{|l|}{ Sources of fund for farming } \\
\hline Personal loan & 85.0 \\
\hline Loan from relatives & 1.3 \\
\hline Loan from bank & 7.5 \\
\hline Loan from cooperative society & 5.0 \\
\hline Loan from issue group & 1.3 \\
\hline
\end{tabular}

Source: Field survey, 2017

\section{Sources of Information on Climate Change}

Information on climate change were sourced mostly from neighbours or friends $(\bar{x}=$ $2.91)$, personal experience $(\bar{x}=2.90)$ and from fellow farmers $(\bar{x}=2.80)$. Agricultural 
extension officers $(\bar{x}=1.19)$, agricultural inputs suppliers $(\bar{x}=0.80)$, family members $(\bar{x}=1.84)$, internet $(\bar{x}=1.38)$, leaflets $(\bar{x}=1.28)$, mobile phones $(\bar{x}=1.48)$, radio $(\bar{x}=$ $1.76)$, television ( $\bar{x}=1.56)$, village leaders $(\bar{x}=1.74)$ and social media (facebook, Whatsapp, twitter etc) were minor sources of information for the farmers.

The findings seem to contradict the claim that mass media such as radio, television, telephone, Internet, and newspaper/ bulletin played significant role in the dissemination of agricultural technologies among Farmers in Kaduna North Local Government Area of Kaduna State (Ariyo, Okelola, Aasa, Awotide et. al, 2013). Conventionally, extension agents are expected to be one of the major sources of information for the farmers. It suggests limited involvement of extension agents in creating awareness and building capability of farmers for climate change adaptation, which can be attributed to several factors including inadequate number of extension agents and poor funding. Reliance on fellow farmers and neighbours for information on climate phenomenon is inadequate for high literacy and innovative response by the farmers.

Table 4: Sources of information on climate change

\begin{tabular}{lll}
\hline Variable & Mean & Std. Deviation \\
\hline Agricultural extension officers & 1.19 & 0.55 \\
Agricultural inputs suppliers & 1.61 & 0.80 \\
Family members & 1.84 & 0.46 \\
Internet & 1.38 & 0.70 \\
Leaflets & 1.28 & 0.60 \\
Mobile phone & 1.48 & 0.76 \\
Neighbours or friends & $2.91^{*}$ & 0.36 \\
Personal experience & $2.90^{*}$ & 0.34 \\
Radio & 1.76 & 0.75 \\
Television & 1.56 & 0.78 \\
Village leaders & 1.74 & 0.84 \\
Social media (facebook, Whatsapp & 1.34 & 0.69 \\
twitter etc) & $2.80^{*}$ & 0.58 \\
Fellow farmers & &
\end{tabular}

*Sources of information; Field survey, 2017

\section{Indigenous Strategies Employed by Farmers}

Table 5 reveals that use of organic manure $(\bar{x}=2.91)$, prompt weeding $(\bar{x}=2.79)$, crop diversification $(\bar{x}=2.75)$, early harvesting $(\bar{x}=2.74)$ early planting crops $(\bar{x}=$ $2.68)$, crop rotation $(\bar{x}=2.68)$. Others include planting early maturing varieties $(\bar{x}=$ 2.59), adoption of irrigation techniques ( $\bar{x}=2.46)$, minimum soil tillage $(\bar{x}=2.26)$ and avoid bush burning ( $\bar{x}=2.13$ ) were the indigenous strategies employed by cucumber farmers. This finding is in line with earlier work by Ajani, Mgbenka and Okeke (2013), who reported that some indigenous strategies that serve as important insurance against rainfall variability were diversification of drought tolerant and/or resistant crops, efficient use of available water, and multiple cropping. This reduces the risk of complete crop failure, since different crops are affected differently by climate change. 
Local farmers are known to have practiced the fallow system of agriculture, forestry, use of cover cropping for preservation of soil nutrient and moisture. However, with growth in population, the length of fallow, agroforestry, and use of cover cropping have been reduced. Although, earlier work by Ajani et al. (2013) reported that organic manure, mulching and agroforestry were adopted by farmers in the face of climate change so as to moderate soil temperatures and extremes, suppress diseases and harmful pests and conserve soil moisture.

Table 5: Indigenous strategies employed by cucumber farmers

\begin{tabular}{lll}
\hline Variable & Mean & Std. Deviation \\
\hline Use of organic manure & $2.91^{*}$ & 0.36 \\
Crop diversification & $2.75^{*}$ & 0.61 \\
Early planting crops & $2.68^{*}$ & 0.47 \\
Minimum soil tillage & $2.26^{*}$ & 0.71 \\
Use of mulching & 1.31 & 0.61 \\
Use of cover cropping & 1.26 & 0.52 \\
Agroforestry practices & 1.25 & 0.56 \\
Planting early maturing varieties & $2.53^{*}$ & 0.68 \\
Adoption of irrigation techniques & $2.46^{*}$ & 0.81 \\
Early harvesting & $2.74^{*}$ & 0.59 \\
Avoid bush burning & $2.13^{*}$ & 0.77 \\
Use of compost manure & 1.46 & 0.71 \\
Prompt weeding & $2.79^{*}$ & 0.52 \\
Crop rotation & $2.68^{*}$ & 0.59 \\
Use of early maturing varieties & $2.59^{*}$ & 0.65 \\
Use of improve/resistant varieties & 1.98 & 0.87 \\
\hline
\end{tabular}

*Indigenous strategies employed; Source: Field survey, 2017

\section{Challenges of Cucumber Farmers in Adapting to Climate Change}

The respondents indicated that challenges to adapting cucumber production to climate change were non-availability of processing facilities $(\bar{x}=2.76)$, nonavailability of credit facility $(\bar{x}=2.74)$, non-availability of storage facilities $(\bar{x}=2.75)$, high cost of labour $(\bar{x}=2.48)$, limited income $(\bar{x}=2.58)$ and poor market facility $(\bar{x}=$ 2.36). Issues on communal system of land ownership $(\bar{x}=2.16)$, irrigation $(\bar{x}=2.10)$ and lack of access to pest/diseases resistant varieties $(\bar{x}=2.03)$ were also considered as challenges by cucumber farmers. This finding corroborates with earlier work by Benhin (2006), who reported that across African countries, lack of access to credit or saving, water, appropriate seeds varieties, security of property rights, market access and lack of adequate information about climate change are some of the major problems encountered by farmers in adapting to the effects of climate change. The farmers encountered both institutional, economic and production challenges in adapting to climate change. 
Table 6: Challenges cucumber farmers faced as a result of using adaptive strategies

\begin{tabular}{lll}
\hline Variable & Mean & Std. Deviation \\
\hline Poor market facility & $2.36^{*}$ & 0.83 \\
Non-availability of credit facility & $2.74^{*}$ & 0.61 \\
Non-availability of processing facilities & $2.76^{*}$ & 0.53 \\
Non-availability of storage facilities & $2.75^{*}$ & 0.56 \\
High cost of farm labour & $2.48^{*}$ & 0.69 \\
Poor access to information sources & $2.30^{*}$ & 0.82 \\
Limited income & $2.58^{*}$ & 0.61 \\
Communal system of land ownership & $2.16^{*}$ & 0.82 \\
Lack of water for irrigation & $2.10^{*}$ & 0.85 \\
Lack of access to early maturing varieties & 1.79 & 0.74 \\
Lack of access to pest/diseases resistant & $2.03^{*}$ & 0.89 \\
varieties & & \\
\hline${ }^{*}$ Challenges; M mean. &
\end{tabular}

${ }^{*}$ Challenges; $\mathrm{M}=$ mean.

Source: Field survey, 2017

\section{Conclusion and Recommendation}

Cucumber production is still at subsistence level and farmers lack access to credit for increase production. The producers depend on other farmers for information on climate change. Although, cucumber farmers adopted numerous indigenous adaptive strategies to climate change, but they are still faced with a number of institutional, economic and production challenges. There is need for extension workers to utilize the power of the media- radio, television, newspapers, posters, internet, hand bills, bill boards, etc- in strengthening climate change awareness and communicating effective response strategies to farmers. Communicating climate change involves the provision of information, facilitating policy and public dialogue, and encouraging accountability. They should mobilize farmers in group to facilitate access to credit and linkage to good market. Innovative adaption technologies need to be provided by research institute for greater efficiency in adapting to climate change.

\section{References}

Ajani, E. N., Mgbenka, R.N., and Okeke, M.N. (2013). Use of Indigenous Knowledge as a Strategy for Climate Change Adaptation among Farmers in sub-Saharan Africa: Implications for Policy. Asian Journal of Agricultural Extension, Economics \& Sociology 2(1):23-40. ,Available online at www.sciencedomain.org. .

Apata T.G., Samuel, K. D. \& Adeola, A. O. (2009), Analysis of Climate Change Perception and Adaptation among Arable Food Crop Farmers in south Western Nigeria. Paper presented at the Conference of International Association of Agricultural Economics pp. 2-9.

Ariyo, O.C, Okelola O.E, Aasa, O.S, Awotide O.G, Aaron, A.J and Oni, O.B ( 2013), Assessment of the Role of Mass Media in the Dissemination of Agricultural Technologies among Farmers in Kaduna North Local Government Area of 
Kaduna State, Nigeria. Journal of Biology, Agriculture and Healthcare. Vol.3, No.6, retrieved from:http://www.docstoc.com/docs/159341316.

Arunkumar, K. H. Ramanjinapa, V\& Ravishankar, M. (2011). Path Coefficient Analysis in F2 Population of Cucumber (Cucumissativus L.). Plant Archives. 11: $471-474$.

Bamire, A. S., Abdoulaye, T., Sanogo, D., \& Langyintuo, A. (2010). Characterization of maize producing households in the Dry Savanna of Nigeria. CIMMYT

Benhin J.K.A. (2006), CEEPA Discussion, 21. CEEPA, University of Pretoria, South Africa.

Enete AA, Ignatius I.M. Josephat C.M, Anthony N.O, Elizabeth A.O, Fidelis E (2011). Indigenous Agricultural Adaptation to Climate Change: Study of Southeast Nigeria. Afri. Tech. Policy Studies Network (ATPS); Research Paper Number 6. rganized by the Department of geography, university of Nigeria, Nsukka.

Federal Republic of Nigeria (2006), National Census 2006. Abuja; National Population Commission

Heinemann, E. (2012). The role and limitations of producer associations. European forum for rural development cooperation. 4 September, Mont Pellier.

International Panel on Climate Change, (IPCC). (2007). Climate change 2007: Impacts, adaptation and vulnerability: Contribution of Working Group II to the Fourth Assessment report of the IPCC. Cambridge UK: Cambridge University Press.

National Bureau of Statistics (2007) Legal notice on publication of the details of the breakdown of the national and state provisional totals, 2006 census. National Bureau of Statistics Official Gazette (FGP 71/52007/2,500(OL24). Retrieved July 25, 2016 www.nigerianstat.gov.ng

National Population Commission (2006) Nigeria federal government initiative of individual head count spread, state by state MOFINEWS6(3): 7 .

Odoemelam and Ajuka (2015), Indigenous Knowledge System and Environmental Conservation Practices in Umuahia South Local Government Area Abia State Http://Www.Academia.Edu/33653093/

Oluwasusi J.O, Tijani SA (2013). Framers Adaptation Strategies to the Effect of Climatic Variation on Yam Production: A Case Study in Ekiti State, Nigeria. Agrosearch 13(2):20-31. 
Ozor, N. (2009). Understanding Climate Change: Implications for Nigerian Agriculture, Policy and Extension. Paper presented at the National conference on climate change and the Nigeria Environment. Organized by the Department of Geography, university of Nigeria, Nsukkam 29 June-2 nd July.

Shetty, N.V and Wehner, T.C. (2002). Estimation of fruit grade weights based on fruit number and total fruit weight in cucumber. Hort. Sci., 37: 1117-1121.

United States Department of Agriculture, Agricultural Research Service, Nutrient Data Laboratory. (2014). USDA National Nutrient Database for Standard Reference, Release 27. $128 \mathrm{pp}$. 